PEDAGÓGUSKÉPZÉS, 9 (38), 2011/3-4.

\title{
A JÖVŐ PEDAGÓGUSAI ÉS AZ INKLUZÍV NEVELÉS, AVAGY HOL TARTUNK HALLGATÓINK INTEGRÁLT NEVELÉSRE VALÓ FELKÉSZÍTÉSÉBEN?
}

\section{N. Tóth ÁGNES}

a Nyugat-magyarországi Egyetem Művészeti, Nevelés- és Sporttudományi Karának egyetemi docense

tagnes@mnsk.nyme.hu

\begin{abstract}
A többségi pedagógusoknak a sajátos nevelési igényü tanulók integrált oktatására való felkészitése számos kérdést vet fel: Milyen tanárokat kell ehhez képezni? Milyen jogokat és jogositványokat kell a befogadó tanároknak élvezniük? Mit értünk tanári sokoldalúság alatt? Követelmény-e a tanári sokoldalúság minden tanárral szemben? (Barton, 2000) Írásunkban rávilágítunk arra, mit tettünk eddig, és mit kell a jövöben tennünk azért, hogy az intézményünkből, a Nyugat-magyarországi Egyetem Savaria Egyetemi Központból kikerülö hallgatók minden tekintetben megfeleljenek a pedagógusokkal szemben támasztott közoktatási igényeknek. E kihívások közül a sajátos nevelési igényü tanulók integrált oktatására való felkészitést kiemelve, helyi tanterveket, tantárgyi programokat elemezve, próbálunk választ adni a kérdésre.
\end{abstract}

\section{Bevezeto}

A hazai pedagógiai gyakorlatnak évtizedek óta dilemmát okoz a különleges bánásmódot igénylő tanulók többiekkel együtt foglalkoztatása (nevelése, tanítása), miközben Európában, az Egyesült Államokban ennek fél évszázados gyökerei vannak. A magyarországi jogi környezet e téren viszonylag gyorsan követte a mintát, ami váratlanul, mondjuk ki őszintén, felkészületlenül érte a pedagógusokat. A helyzet kezelésére maga az iskolarendszer sem volt igazán felkészülve, hiszen a pedagógusoknak sokáig nem kellett ilyen problémákkal szembenézniük (Hanák, 2009). Így nem elhanyagolható azoknak a szakembereknek az aránya, akikből e felkészületlenség szakmai bizonytalanságot, ambivalens érzéseket vagy nemtetszést váltott ki. Tapasztalható például, hogy az intézmények helyet adnak a sajátos igényü (SNI) tanulónak, saját szokásaikon, szemléletükön azonban alapvetően nem változtatnak a befogadás révén, inkább az integrált gyermektől várnak azonosulást. A folyamat nem más, mint a speciális igényü tanulóknak egyszerü asszimilációja (Csányi et al., 2007).

Papp Gabriella (2002) még az integrált oktatás általánossá tétele előtt (1993. évi LXXIX. Törvény a közoktatásról, 2003. évi módositása) figyelmeztetett tanulmá- 
nyában arra a problémára, hogy a többségi pedagógusok a képzés során nem találkoznak az integratív pedagógia módszereivel, vagy ezeket csak felszínesen sajátítják el. Később, a tanári kompetenciák kifejtését tartalmazó miniszteri rendelkezésben (15/2006. OM (IV. 3.) már nagyobb hangsúlyt kap a tanulói személyiség és közösségfejlesztés, valamint a pedagógusok team-munkája. Csépe Valéria (2008) szerint, a SNI tanulókkal és az integrációval kapcsolatos tananyagoknak a teljes pedagógusképzést át kellene hatniuk a sikeres befogadási gyakorlat érdekében.

\section{A tanárjelöltek integrációra való felkészítésének szombathelyi hagyományai}

A Nyugat-magyarországi Egyetem Savaria Egyetemi Központ, korábban Berzsenyi Dániel Főiskola (továbbiakban NyME SEK) szombathelyi tanárképző karainak képzési programjain felfedezhetőek a közoktatási helyzetképpel egybecsengő változások. Vizsgálatunk az irattárban elhelyezett dokumentumok elemzésén alapul: óra- és vizsgatervek; pedagógiai, pszichológiai tárgyleírások, tantárgyi tematikák.

A 2002. évi tantervi modernizáció (kreditrendszer és az elektronikus tanulmányi rendszer bevezetése) előtti intézményi óratervekben a klasszikus pedagógiai tárgyak (neveléstörténet, neveléselmélet, oktatáselmélet vagy azok szinonimái) éppen csak súrolták a különleges igényü tanulókkal való foglalkozás elméleti és gyakorlati alapjait. Külön stúdiumként nem is fordult elő a fogyatékkal élők integrációjára történő felkészítés, noha az integrált oktatás lehetősége már az 1993. évi (LXXIX.) közoktatási törvényben megjelent.

Később, a 111/1997 és a 200/2000 Kormányrendeletek elöírásainak érvényre juttatása, nevezetesen a tanári képesítővizsga és a kreditrendszer bevezetése nélkülözhetetlenné tette a tanárjelöltek komplex pedagógiai-pszichológiai látásmódjának kialakítását, ennek érdekében pedig új tantárgyi struktúra alkalmazását. A 2002. évi intézményi program bevezetése jelentős változást hozott, a hallgatók szakmai felkészítését viszont továbbra is a hagyományos pszichológiai és pedagógiai stúdiumok biztosították. Sem a kurzusok címei, sem a dokumentumok (tantárgyi tematikák, óra- és vizsgatervek) áttanulmányozása nem győzi meg a vizsgálódót a hallgatók szemléletformálásával kapcsolatos szemináriumi aktivitásokról, ezért úgy véljük, a tanárjelöltek ebben az időszakban csupán elenyésző információt kaphattak a sajátos nevelési igényekről és az iskolai integráció szakmai feltételeirôll.

A „Komplex pedagógiai-pszichológiai szigorlat” vizsgatervbe építése az intézményben, 2003-ban történt meg, ezzel teret kaptak a speciális tartalmú stúdiumok is, mint Tanári személyiség- és kommunikációfejlesztés; Pedagógia speciális kurzus 1-2; Pszichológia speciális kurzus 1-2; Hátrányos helyzetủ fiatalok nevelése; Gyakorlati pedagógiai kommunikáció (mikrotanítás). A Pedagógiai speciális kurzus 1. tantárgy keretén belül tíz, a Pedagógia speciális kurzus 2-ben öt stúdiumból lehetett szabadon választani. Mivel a speciális kurzusok bemeneti feltétele a komplex 
szigorlat volt, így azok tartalma - értelemszerúen - nem lehetett szigorlatköteles, vagyis a hallgatóknak csak töredéke, és ők is pusztán szabad választás alapján tanultak a sajátos igényekröl. Az óra- és vizsgatervből látszik, hogy az említett tantárgyak gyakorlati jeggyel záruló szemináriumok voltak, félévenkénti 15-30 kontaktórában. A speciális kurzusok közül egyet-egyet (V. vagy VI. félévben) minden tanár szakos hallgatónak teljesítenie kellett, de kizárólag a komplex (pedagógiai-pszichológiai) szigorlat (IV. félév) sikeres letétele után. A téma iránt érdeklődők választhatták például a Felzárkóztató és fejlesztő pedagógiát, vagy a Tanulási folyamatok irányítását, amelyeknek tartalma közelebb állt az integrációra felkészüléshez, de - szemben a Hátrányos helyzetű fiatalok nevelése (előadás és szeminárium) tárggyal -, ez csupán opcionális lehetőség maradt, és nem kötelezettség.

Meg kell jegyezni, hogy e stúdiumok hallgatósága az akkori 400-500 fős évfolyamoknak csak fele - harmada lehetett, így kimondható, hogy az évtized elején végzettek kisebb hányadának problémaérzékenysége bizonyosan erősödött, de az évfolyamok másik fele gyakorlatilag semmiféle vagy nagyon elhanyagolható mértékü felkészítésben részesült.

A 2005-ben módositott helyi tantervben az Egyéni pszichológiai és pedagógiai gyakorlatokat a korábbi 15 óráról 45 órára sikerült növelni, megtartva a hátrányos helyzettel és a speciális bánásmódot igénylőkkel való foglalkozások időtartamát. A sajátos nevelési igényekről továbbra is speciális stúdiumok keretében hallhattak a tanárjelöltek, és e kurzusok választását még mindig a hallgatók érdeklődése határozta meg. Az akkori (2005/06. tanév), 300-400 fös évfolyamoknak, az elektronikus tanulmányi rendszer (NEPTUN) adatai alapján, hozzávetőlegesen fele élt ezzel a lehetőséggel. A tantárgyi programból kiderül, hogy a kurzusban helyet kapott a gyógypedagógiai alapirodalom, és az integrált oktatás népszerüsítése is.

A 2005. évi tartalmi korrekcióra a HEFOP 2.1.1. B. komponensében (SULINOVA) történő intézményi szintü közremüködés (felsőoktatási képzési programok fejlesztése, képzési anyagok elóállítása) hatott. Ekkor ugyanis, kísérleti jelleggel, két féléven keresztül az évfolyamoknak közel háromnegyede (200-250 fö) kötelező stúdiumokon vett részt a sajátos igényekről, illetve az integrált oktatásról szóló tananyagok kipróbálásában. A tananyagok sikere a hallgatók között azt eredményezte, hogy e tananyagokat később folyamatosan alkalmazták az intézményben, s ez a tartalom a Pedagógia speciális kurzus 1-2. c. tantárgyakban állandósult. A 2005-ös óra- és vizsgatervben a Hátrányos helyzetü fiatalok nevelése továbbra is elöadás és szeminárium (1/1; kollokvium és gyakorlati osztályzat) formájában szerepelt, míg a Pedagógia speciális kurzusok korábbi kínálata (Felzárkóztató és fejlesztö pedagógia; Tanulási folyamatok irányitás) és a kurzusok iránti érdeklődés nem változott, a projekt befejezése azonban lényegesen szükítette a résztvevők körét. A speciális tárgyakat ekkor már (2006) csak az évfolyamoknak a fele, 100-150 hallgató hallgatta. Az információhordozók, amelyeket a projekt ideje alatt alkalmaztunk (brosúrák, filmek, szakanyagok), különös értéket képviseltek a résztvevők érzéke- 
nyítésében. A hallgatók pozitív viszonyulása a sajátos nevelési igényekhez az általuk választott szakdolgozati és tudományos diákköri témák jellegében és mennyiségében is észrevehető volt (1. ábra).

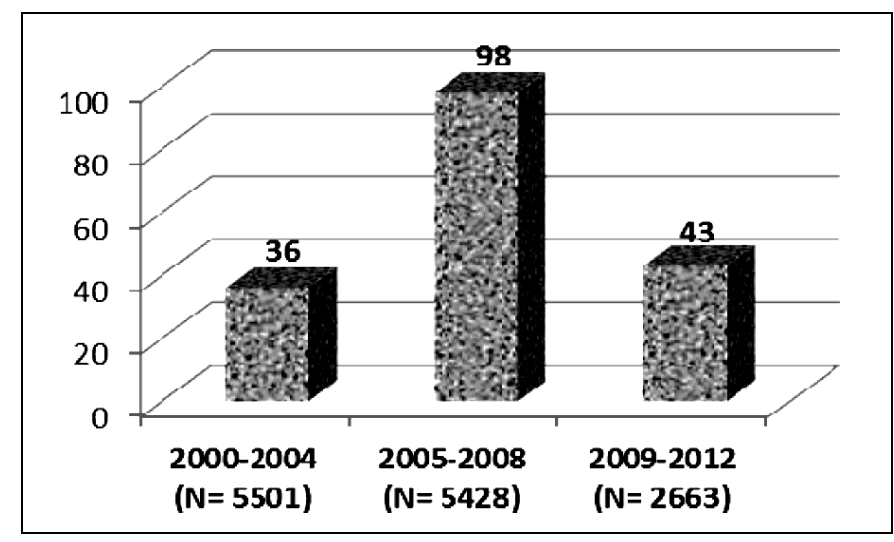

1. ábra: A szakdolgozati adatbázis tárgyszavas (fogyatékosság; integráció; hátrányos helyzet) elemzésének eredménye

Az 1. ábra mutatja, hogy míg 2000 és 2004 között 5501 végzős közül (a könyvtári adatbázisban regisztrált diplomamunkák száma alapján) 36 fő $(0,65 \%)$ írt szakdolgozatot a sajátos igényekkel kapcsolatos témákból, például integrált oktatás, fogyatékkal élők helyzete stb., addig 2005 és 2008 között, 5428 végzősböl 98 fő $(1,8 \%)$ foglalkozott ezzel a területtel. Később viszont (2009-2012), 2663 végzősből $(1,61 \%)$ 43 fő dolgozott fel hasonló problémát. Az érdeklődés tehát 2005 után jelentősen nőtt, ami részben a projektnek, részben pedig az újabban indított szakirányú továbbképzéseknek köszönhetö, de a 2009-2012-es csökkenés az ugyancsak visszaesett hallgatói létszámhoz viszonyítva, nem számottevő $(0,19 \%)$.

Meg kell említeni továbbá, hogy a Demokratikus Ifjúságért Alapitvány (DIA) támogatásában, noha az általa kínált tananyag-témák alapvetően a 14-18 éves korosztály szociális kompetenciáinak fejlesztését célozták, újabb két tanéven keresztül (2006-2008) nyílt lehetőség arra, hogy a leendő tanárok nagyobb létszáma ismerkedjen meg az eltérő szociális és tanulási teljesítményeket mutató (akár SNI) tanulók foglalkoztatásának sajátosságaival. Ebben a programban ugyanis a hallgatóknak külső (választott) iskolai terepgyakorlaton kellett tanfolyamokat szerveznie, és vezetnie az érintett korosztály számára, így lehetőségük nyílt a reális oktatási környezet megtapasztalására.

Látható tehát, hogy a pedagógusképzés 2006-ig a 111/1997-es kormányrendelet alapján történt az intézményben, néhány szemléletformáló vagy módszertani projekt adaptációjával kiegészítve. 
A kétszintü (bolognai rendszerü) tanárképzés 2006-ban történt bevezetése gyökeres változásokat hozott a pedagógusok felkészítésében, hiszen a kompetencia alapú képzés valódi szakmai tárgyai a mesterképzésbe (MA) kerültek, ezáltal a súlyuk is megnövekedett. Az alapozó (BA) képzésben a pedagógiai modul mindössze 10 kreditet tartalmaz (1. táblázat), és a benne oktatott tantárgyaknak - a helyi sajátosságok szerint - egyike sem foglalkozik behatóan a speciális bánásmóddal és az integrált oktatással. A tantárgyak tréning jellegü tartalmakat ölelnek fel. E keretben az oktatók igyekeznek kialakítani a tanári pálya iránti hallgatói érdeklődést, és foglalkoznak a hivatás gyakorlásához nélkülözhetetlen kompetenciák fejlesztésével, de a sajátos nevelési igényü tanulók fogalma, vagy a velük való speciális bánásmód, hangsúlyosan nem jelenik meg a tárgyleírásokban, indirekt módon azonban a jelen van a feldolgozott témakörök között. Gondolunk itt például a kommunikációra, a konfliktusok hatékony kezelésére, a tanári szerepekre vagy a reflektív gondolkodásra. A feldolgozott szakirodalmi forrásokat saját élményü tantermi gyakorlatok és külső (gyakorló) iskolai látogatások teszik élményszerüvé. Bár a gyakorló iskolában a speciális igényü tanulók száma elhanyagolható, de az e tantárgy keretében tett látogatás csak részben szolgálhatja a hallgatók integrált oktatásra való felkészítést. A látogatások célja, az iskolai alapdokumentumok és a pedagóguspálya jellemvonásainak megismerése, így ennek során legfeljebb arra nyílik lehetőség, hogy a pedagógiai program megfelelö fejezetéből vagy az osztálynaplókból, tantervekből tájékozódjanak a hallgatók a sajátos igények intézményi szintü kielégítésének kötelezettségeiről, módjairól. A gyakorló iskolai tanárokkal folytatott beszélgetések alkalmával azonban - a szemináriumvezető oktatókkal történt előzetes témaegyeztetés (interjúkérdések) - hatására mindenképpen felvetődik a kérdés: hogyan látja a közoktatásban dolgozó kolléga az integrációt, mint nevelési problémát, van-e tapasztalata speciális igényü (SNI vagy más kultúrkörből származó) tanulók tanításában.

1. táblázat: A tanári alapozó képzés (BA) pedagógiai, pszichológiai modulja

\begin{tabular}{|l|c|c|c|c|c|c|}
\hline \multicolumn{1}{|c|}{ Tárgynév } & Kredit & Jelleg & Félév & Elmélet & Gyak. & Követelmény \\
\hline $\begin{array}{l}\text { A nevelés történeti-antro- } \\
\text { pológiai alapjai }\end{array}$ & 2 & Köt. & 3 & 15 & 15 & Kollokvium \\
\hline Bevezetés a pszichológiába & 2 & Köt. & 3 & 15 & 15 & Kollokvium \\
\hline $\begin{array}{l}\text { Pedagógiai képességek } \\
\text { fejlesztése }\end{array}$ & 2 & Köt. & 3 & 0 & 30 & $\begin{array}{c}\text { Minösített } \\
\text { aláírás }\end{array}$ \\
\hline $\begin{array}{l}\text { Bevezetés a pedagógia } \\
\text { elméletébe és kutatási } \\
\text { módszereibe }\end{array}$ & 2 & Köt. & 4 & 15 & 15 & $\begin{array}{c}\text { Gyakorlati } \\
\text { jegy }\end{array}$ \\
\hline A tanári mesterség alapjai & 2 & Köt. & 4 & 0 & 30 & $\begin{array}{c}\text { Minősített } \\
\text { aláírás }\end{array}$ \\
\hline
\end{tabular}




\section{A közeli múlt és a jelenlegi képzés sajátosságai}

Intézményünkben a kompetencia alapú tanárképzés (tanári MA) 2009 szeptemberétől indult, a hallgatói létszám ezzel egyidejűleg jelentősen csökkent. 2006 és 2010 között szinte csak a korábban lemorzsolódott, ún. „kifutó tantervek szerint tanuló” és a bolognai rendszerü (BSc) képzés nappalis hallgatói voltak a rendszerünkben. A levelezős (kiegészítő egyetemi képzés) hallgatóinak létszáma is csökkent, de nem ilyen nagymértékben. Annak a kérdésnek a megválaszolásához, hogy előnyösen befolyásolták-e a tartalmi és létszámváltozások a tanárjelöltek integrációra felkészítését, mindenekelött a 2009-töl hatályos tanári mesterképzés újonnan akkreditált tantervét érdemes áttekinteni. E helyen, a terjedelmi korlátokra figyelemmel, teljes bemutatás nélkül, csak a témára vonatkozó legjellemzőbb sajátosságokat foglaljuk össze.

A tantervben a szakmai törzstárgyak (minden hallgató számára kötelezö) között hangsúlyosan jelennek meg az integratív pedagógiának alapot nyújtó tantárgyak, úgy mint Az értelmi fejlödés pszichológiája; A személyiség lélektan és A pedagógiai kutatás módszertana. A differenciált szakmai ismeretek között (kötelezően választható) a tréningek (csoportépítés, konfliktuskezelés), a személyiségfejlődés zavarai, a családpedagógia, a differenciáló pedagógia és a tanulásmódszertan kapnak helyet. A kötelezően választható tárgyak közül félévente azt és annyit hirdet meg az intézmény, amennyit a hallgatói létszám szükségessé és az oktatói kapacitás lehetővé tesz. Előremutató tapasztalat viszont, hogy a Differenciáló pedagógia és a Tanulásmódszertan a kezdetektől (2009. öszi szemeszter) fogva minden félévben meghirdetésre kerül, s mindkettőt, minden hallgatónak választania szükséges. Ezzel az intézkedéssel nagy lépést tettünk meg a hallgatók „befogadó pedagógussá” válása felé.

A Differenciáló pedagógia c. tantárgy tematikájából például kitünik, hogy a résztémák és a feldolgozott szakirodalom is segíti a hallgatókat az integrált oktatásban való aktív részvételre. A félév végi zárthelyi dolgozat kérdéseiről e helyen nincs megbízható információ, a témakörök és a tananyag azonban sejtetik az értékelés irányait.

A Tanulásmódszertan c. tantárgy programjában a tanulás, mint pszichikus folyamat értelmezésétől a tanulási motiváción át a tanulási képességig terjed a hallgatók felkészítése. A tőlük elvárt feladat pedig önálló pedagógiai tanulás-diagnózis elvégzésére irányul. E tantárgy tartalmát külső iskolai gyakorlat (Közoktatási gyakorlat III.) is kiegészíti, amelynek során a hallgatók tanórai szituációban figyelhetik meg a gyerekek tanulási sajátosságait.

A Közoktatási (I-II-III) gyakorlatokat külön is ki kell emelni, nem csak azért, mert funkciójuk szerint élményszerüvé teszik a képzés elméleti stúdiumait, hanem mert e gyakorlatok során a hallgatók a gyakorló iskolában ismerkednek az intézményi alapdokumentumokkal, és beszélgetnek a pedagógusokkal is, akiktől a pálya szépségeire vagy nehézségeire vonatkozó, reális információkat szerezhetnek. A Közoktatási gyakorlat I, nevelési helyzetek, illetve a személyiség vagy családi problémák előfordulására; a II, a tanóravezetés, a tanári munka megfigyelésére, míg a III, a tanu- 
lási folyamatok irányítására, a tanulásmódszertan elsajátítására koncentrál, egyben pedig lehetőséget kínál a tanórai munka beható megismerésére.

Az intézménynek a hallgatók számára készített és az egységes tanulmányi rendszerben kezelt mintatanterve olyan differenciált szakmai ismereteket is tartalmaz, amelyek a speciális igények kielégítéséhez nélkülözhetetlenek. Ezek például a Pedagógiai esetmegbeszélés; Osztályfönöki szerep; Inter-és multikulturális nevelés továbbá az Inkluziv iskola. Az említett tárgyak a kötelezően választható stúdiumok kínálatát bővítik, ám ezeket az alacsony hallgatói létszám és a képzés kreditszámai következtében nem mindig lehet indítani. Tény, hogy az integratív pedagógia felé közelítő, korábban már említett tartalmú kurzusok (tanulásmódszertan, differenciáló pedagógia) hallgatóinak aránya a képzésben 100 százalék, de a sajátos nevelési igények részletesebb elemzését deklaráltan magába foglaló inkluzív pedagógiát a pedagógiatanárok kivételével az utolsó három évben senki nem tanult. ${ }^{1}$

A gyakorlati képzés új (2009-ben bevezetett) szisztémájáról joggal feltételezhető, hogy kompenzálja az elméleti felkészítés hiányosságait és bevezeti a hallgatókat az iskolai munkának e területére, ezért érdemes rápillantani az intézmény nyújtotta szakmai gyakorlatok rendszerére. E gyakorlatok során kötelező feladat az iskola dokumentumainak tanulmányozása, ami módot ad, hogy a témába vágó terület iskolai szabályozásával, praxisával ismerkedésre. Az elvégzendő feladatok (Virághné, 2011) tanórai és tanórán kívüli iskolai feladatokra irányulnak, továbbá nevelési tanácsadóban, illetve integrált nevelést folytató intézményekben történnek. Ahogyan Iker János írja, ,.... a féléves, összefüggő szakmai gyakorlat célja nem pusztán a szaktárgy tanításának további gyakorlása, hanem az iskola és benne a tanár komplex oktatási-nevelési feladatrendszerének elsajátítása, illetve az iskolát körülvevő társadalmi, jogszabályi környezet, valamint a szakszolgálatok és a szakmai szolgáltató intézmények megismerése a közoktatás terepviszonyai között.” (2011, 62. o.) A hangsúlyt a közoktatási terepviszonyokon érezzük, beleértve a hátrányos helyzetủ tanulók iskolai szocializációjának jelentős feladatait is.

Az összefüggő egyéni gyakorlatokat a 2010/11. tanév tavaszi szemesztere óta a Regionális Pedagógiai Szolgáltató és Kutatóközpont (PSZK) szervezi. Az elmúlt két tanév alatt összesen három fö nappalis és 528 fö levelezős hallgató gyakorlatát koordinálták. A három nappalis és 66 fö levelezős 32-32, míg a többi 462 levelezős 16-16 tanítási órát abszolvált, 66 partnerintézményben (szerződött iskolák). Tudni lehet, hogy a végzősök a partneriskolák közül általában negyvenet szoktak választani tanítási gyakorlatuk helyszínéül ( $\overline{\mathrm{X}}=13-14$ hallgató per iskola), amiből látjuk, hogy bizonyos iskolák népszerúsége erőteljesebb a végzősök között, így elmondható, hogy ezeknek napi gyakorlatából szerez tapasztalatot a hallgató. Nincs viszont megbízható adat arra vonatkozólag, hogy a választott intézmények hányad része

${ }^{1}$ Ez nem jellemző, az egyéni fejlesztő, differenciáló szakirányú továbbképzési szak hallgatóira, akiknek képzése teljességgel e témára irányul. 
foglalkozik integrált neveléssel, amibe a végzősök is betekinthetnének. Arról sincs információnk, hogy a hallgatóknak hányad része szerzett tanítási gyakorlatot szakképzett mentor irányításával, aki esetleg tájékoztatja őt a SNI tanulók helyzetéről és a velük való bánásmódról annak ellenére is, ha a gyakorlatnak helyet adó iskolában nincs ilyen tanuló. Annyi bizonyos, hogy a szakképzett mentorok erre a 2010. évi TÁMOP keretben történt 120 órás mentorképzésben felkészítést kaptak, amit a PSZK szervezett, és a régióból (Györ, Vas, Zala megye) összesen 112 pedagógus vett részt. Közülük, a PSZK adatai szerint, 70 fö került eddig ténylegesen mentori szerepbe. A tanfolyam az EKF akkreditált képzése alapján zajlott, és egyebek mellett a kapcsolati kommunikáció, a reflektivitás, az osztályfőnöki munka, a speciális nevelési területek, a multikulturális nevelés, a pedagógiai munkát segítő szakemberek, intézmények, a tanulói kompetenciák fejlesztése és a tehetséggondozás jelentette a föbb tematikai csomópontokat (PSZK Adatbázis, 2012).

Az összefüggő egyéni gyakorlat másik részében (szintetizáló szeminárium) szintén a PSZK szervezésében, minden hallgató (két-két órában) mérés-értékeléssel, illetve a nevelési tanácsadó munkájával ismerkedik. E szemináriumok tartalmára a hallgatók számára interneten közzétett előadásvázlatok (PPT) alapján következtethetünk. A prezentációk tanúsága szerint, a nevelési tanácsadóról szóló előadás kitér a sajátos igényủ tanulókra, és ezt diagnosztikai megközelítésből teszi. Az integráció pedagógiai kérdéseinek kifejtése viszont a dokumentum alapján nem igazolható.

A szemináriumi előadások igazolhatóan rendkívül fontos témaköröket ölelnek fel, ám ezek tartalmának egy része - ismerve a hallgatók előzetes tájékozottságát a közoktatás terepviszonyaitól kissé távolinak tünik. A törvények, jogszabályok vagy a statisztikai elemzések bemutatása felveti a kérdést, elegendő-e a témára szánt két órás időkeret az előképzettség nélkül levő hallgató számára, hogy ezeket megértse és alkalmazni tudja, mert a tőle elvárt (szabadon választható) teljesítmények viszont ezt feltételezik. A feladatok egy része nem nélkülözi a valódi közoktatási gyakorlatot, másik részén azonban, annak (időbeli) előkészíthetősége okán, érdemes elgondolkodni (például leíró statisztikai elemzések, vagy különböző fogalmak elméleti hátterének megvilágítása).

\section{Összegzés}

Az utolsó tíz évben számos felsőoktatási törvény/módosítás, kormányrendelet és egyéb jogszabályok, valamint négy különböző óraterv alapján képeztünk pedagógusokat. A tantervek és tantárgyi programok, figyelemmel a helyi lehetőségekre, korszerü ismereteket igyekeztek nyújtani, ami megnyilvánult abban is, hogy fokozódott a figyelem a különleges bánásmódot igénylő gyermekek iránt. A tanulók integrált neveléséhez szükséges pszichológiai és pedagógiai alapismeretek témakörei (fejlődéslélektan, személyiség lélektan, szociálpszichológia, családpedagógia, differenciáló pedagógia, nevelési tanácsadás stb. tantárgyakban) mindenki számára köte- 
lezően feldolgozandókká váltak, de a speciális ismeretkörök (sajátos igények tipológiája, integratív pedagógia, inkluzív iskola) továbbra sem továbbhaladási kritériumok, így nem is jutnak el mindenkihez.

A tantárgyi programok alapján elmondható, hogy a pedagóguspálya gyakorlásához szükséges korszerü tudás megszerzésének lehetősége a bolognai rendszerü képzés bevezetésével jelentősen javult, ám az iskolai integrációra történő teljes körủ felkészítés további kívánni valókat hagy maga után.

Érdemes foglalkozni a félévi tantárgyi programok sajátosságaival, ti. túlságosan ismeretközpontúak, $\mathrm{s}$ a gyakorlati készségek kialakítására a tanteremben tartott szemináriumok csak részben alkalmasak, hiszen azokon nincs elegendő idő és a körülmények sem megfelelők a befogadó pedagógusi kompetenciák hatékony kialakításához. E hiányosság kiküszöbölése a közeli jövőben éppúgy megoldandó feladat, mint a sajátos nevelési igények részletes elemzése és az integratív pedagógia eröteljesebb hangsúlyozása a képzésben.

\section{Irodalom}

Barton, L. (2000): Market ideologies, education and the challenge for inclusion. In: Harry Daniels and Philip Garner (ed): Inclusive education. Kogan Page Limited, London, UK \& Stylus Publishing Inc. Washington, USA. 62-78.

Csányi Yvonne, Egyed Katalin, Fazekasné Fenyvesi Margit, Gaál Sándorné, Girasek János, Glauber Anna, Kovátsné Németh Mária, Szegál Borisz, Tóth László (2007): Inkluziv nevelés. A tanulók hatékony megismerése. SuliNova Közoktatás-fejlesztési és Pedagógus-továbbképzési Kht., Budapest.

Csépe Valéria (2008): A különleges oktatást, nevelést és rehabilitációs célú fejlesztést igénylő (SNI) gyermekek ellátásának gyakorlata és a szükséges teendők. In: Fazekas Károly Küllö János - Varga Júlia (szerk.): Zöld könyv a magyar közoktatás megújitásáért. ECOSTAT, Budapest, 139-166.

Hanák Zsuzsanna (2009): Hátrányos helyzetủ tanulók továbbtanulásának támogatása speciális tréningprogramok segítségével. In: Bábosik István - Torgyik Judit (szerk.): $A z$ iskola szocializációs funkciói, Eötvös Kiadó, Budapest, 179-187.

Iker János (2011): Pedagógusképzés-továbbképzés (2006-2010). In: N. Tóth Ágnes (szerk.): Változó professzió, változó tanárképzés. Savaria Press, Szombathely, 51-86.

Papp Gabriella (2002): Tanulásban akadályozott gyermekek iskolai integrációja a szakemberek közötti kooperáció tükrében. Magyar Pedagógia, 2. sz. 159-178.

Virághné Szalai Zsuzsanna (2011): A tanári mesterszak összefüggő (féléves) gyakorlatának programja a Nyugat-magyarországi Egyetemen. In: N. Tóth Ágnes (szerk.): Változó professzió, változó tanárképzés. Savaria Press, Szombathely, 87-105.

2003. évi LXI. Törvény a közoktatásról szóló 1993. évi LXXIX. törvény módositásáról. http://www.complex.hu/kzldat/t0300061.htm/t0300061.htm

15/2006. (IV. 3.) OM rendelet az alap-és mesterképzési szakok képzési és kimeneti követelményeiröl. http://net.jogtar.hu/jr/gen/hjegy_doc.cgi?docid=A0600015.OM 